UDC 621.01.

I. N. Matsyuk ${ }^{1}$, Cand. Sc. (Tech.), Assoc. Prof., orcid.org/0000-0002-0861-0933, E. M.Shlyahov', orcid.org/0000-0001-5983-9853, O. I. Yehurnov ${ }^{2}$, Cand. Sc. (Tech.)
DOI: $10.29202 /$ nvngu/2018-3/14

1 - National Mining University, Dnipro, Ukraine, e-mail: shlyahove@nmu.org.ua

2 - Ana-Tems Ltd., Dnipro, Ukraine, e-mail: yegurnov@ yahoo.com

\title{
SOME ASPECTS OF SYNTHESIS OF LINKAGE OF COMPLEX STRUCTURES
}

Purpose. To study possible variants of assemblies of the fourth class Assur group consisting of four links and to evaluate their impact on operation of the mechanism containing this Assur group.

Methodology. The paper shows the results of theoretical study of possible assemblies of the fourth class Assur group in a jaw crusher in which both jaws move. The study was carried out with the help of the MathCAD software.

Findings. It is shown that the planar fourth class Assur group used in the jaw crusher features the following:

- only two assemblies are possible for conventional configuration of three-joint links against the frame;

- assembly mode significantly affects the quality of the crushing process;

- assemblies can be located very close, which can cause spontaneous transition from one assembly to another in heavily loaded mechanisms and result in an emergency situation.

Originality. It has been established that in the planar fourth class Assur group the number of possible assemblies does not exceed two. Very close mutual arrangement of assemblies is possible. Position functions of mechanisms with different assemblies differ from one another.

Practical value. The action algorithm is proposed. Used at synthesis of planar mechanisms of the fourth class, it allows evaluating their possible assemblies.

Keywords: structural group, mechanism assemblies, geometric analysis, jaw crusher, Mathcad program

The problem definition. In the manifold of planar mechanisms used in modern technology, mechanisms pertaining to the second class according to Assur-Artobolevsky classification are dominating. The mechanisms of the third, fourth, and higher classes, called high-class mechanisms (HCMs) are currently applied only marginally. Moreover, the higher the class of a mechanism is, the narrower the scope of their use is.

It is established that HCMs feature more complicated laws of motion of working elements, improved dynamic performance, and, as a whole, they have greater potential.

With a higher class of the Assur group, the number of its possible configurations or assemblies increases. Each assembly has its own characteristics, the study of which is of definite interest.

Analysis of the recent research. HCM studies have been conducted by E. Ye. Peisakh, U.A. Dzholdasbekov, V. G. Khomchenko, L. T. Dvornikov [1] and others.

This century witnesses the tendency to study and implement the HCM extensively in mine engineering equipment.

From 2003 to 2013 there were published patents of the Russia Federation for powered support configuration (Patent No. 2303699) where a fourth class mechanism was used. A number of patents dealt with crushers in which fifth class (No. 2232637) and sixth class (No. 2332260, No. 2423179) mechanisms were used. A jaw crusher with mutually movable jaws (Patent No. 2538108 of the Russian Federation) is based on the fourth class mechanism.

(C) Matsyuk I. N., Shlyahov E. M., Yehurnov O. I., 2018
Methods mathematical become a frequent practice while studying the HCM which are applied numerically by means of computer technologies [2-4]. The vector method [2, 3] and ordinary algebra methods [4] are used.

Usually, lower the class of the mechanism by changing the input and output links or, using one of the moving links as a reference, study the relative motion of the remaining links $[5,6]$.

Furthermore, E. Ye. Peisakh shows that planar fourbar mechanisms of the third and fourth classes can have up to six variants of assembly. The higher the mechanism class and the greater the number of its links are, the greater the number of its assemblies is. The issue of choosing the efficient assembly regarding the functions which the mechanism performs is topical. Thus, the article is devoted to this issue.

Objectives of the article. The purpose of the article is to study the effect of possible variants of assemblies of the fourth class Assur group consisting of four links on operation of the mechanism of a jaw crusher in which both jaws move.

To achieve the purpose in view the following tasks were determined:

- to define the number of possible assemblies of this group;

- to evaluate the influence of the assembly mode on the quality of the crushing process;

- to estimate possible variants of mutual arrangement of assemblies.

The solution of the tasks was to be performed using the popular application software package of MathCAD.

Presentation of the main research. As an example, let us consider a fourth class link mechanism which is the 
basis of a crusher configuration (Patent No. 2538108 of the Russian Federation) with complex motion of two jaws (Fig. 1).

The crusher consists of a power driven crank $O_{1} A-$ 1, jaws $C E-3$ and $B D-4$. Through a three-joint balanced link $E O_{2} D-5$ and a three-joint power driven link $A B C-2$, the jaws make a closed four-bar loop $B C E D$, in which material 6 is crushed. Link 5 is connected with the frame by revolute joint. Link 2 is connected with the drive crank by revolute joint. The crushing parameters are characterised by the degree of change of angle $\delta$ between the direct axes of the jaws.

Let us carry out the analysis of the linkage geometry of the crusher whose scheme is shown in Fig. 2, $a$.

Coordinates of revolute joints $A$ and $G$ of the mecha$\operatorname{nism}(\mathrm{m}): x_{A}=0 ; y_{A}=0 ; x_{G}=-0.35 ; y_{G}=0.8$. Moduli of a vector $(\mathrm{m})$ are: $l_{1}=0.07 ; l_{2}=0.075 ; l_{21}=0.15 ; l_{3}=0.92$; $l_{4}=0.92 ; l_{5}=0.55 ; l_{51}=0.2$. Angles between the vectors being the basic links 2 and 5 are: $\alpha=36.336^{\circ} ; \beta=34^{\circ}$.

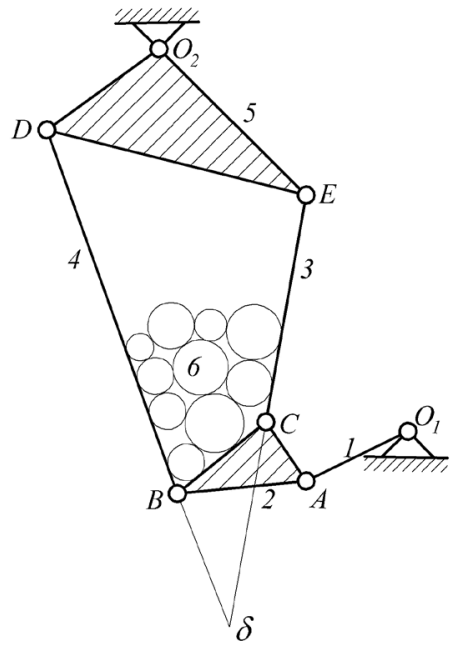

Fig. 1. A schematic diagram of operating principle of a jaw crusher in which both jaws move:

$\delta$ - point of intersection of direct axes of jaws 3 and 4

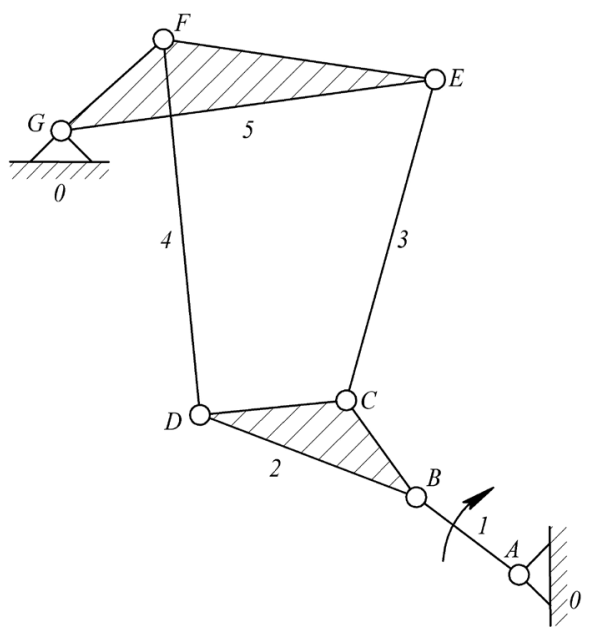

Fig. 2. Linkage of a crusher:

$a$ - scheme; $b$ - vector interpretation of links
Let us substitute corresponding vectors for the mechanism links (Fig. 2, $b$ ). Let us consider two closed vector paths $A B C E G A$ and $A B D F G A$, for which we will write vector loop-closure equations where the vectors are expressed as complex numbers

$$
\begin{gathered}
l_{1} e^{i \varphi_{1}}+l_{2} e^{i \varphi_{2}}+l_{3} e^{i \varphi_{3}}=l_{0} e^{i \varphi_{0}}+l_{5} e^{i \varphi_{5}} \\
l_{1} e^{i \varphi_{1}}+l_{21} e^{i\left(\varphi_{2}+\alpha\right)}+l_{4} e^{i \varphi_{4}}=l_{0} e^{i \varphi_{0}}+l_{51} e^{i\left(\varphi_{5}+\beta\right)} .
\end{gathered}
$$

The modulus of vector $l_{0}$ and angle $\varphi_{0}$ are to be determined from the expressions

$$
\begin{gathered}
l_{0}=\sqrt{\left(x_{G}-x_{A}\right)^{2}+\left(y_{G}-y_{A}\right)^{2}} ; \\
\varphi_{0}=\pi+\operatorname{arctg}\left(\frac{y_{G}-y_{A}}{x_{G}-x_{A}}\right) .
\end{gathered}
$$

Let us solve the problem of finding unknown angles $\varphi_{2}, \varphi_{3}, \varphi_{4}, \varphi_{5}$ with the given value of the angle $\varphi_{1}$. The problem is solved within the Mathcad 11 software program which has a sufficient number of built-in functions to work with complex numbers.

With the help of operational unit Given-Find, given the initial approximation we solve the set problem. The relevant fragments of Mathcad document are presented below.

The given data are

$$
\begin{array}{lcccc}
x_{A}:=0 & y_{A}:=0 & y_{G}:=0.85 \quad x_{G}:=-0.35 & l_{1}:=0.07 \\
l_{2}:=0.042 & l_{21}:=0.15 & l_{3}:=0.92 & l_{4}:=0.92 \\
l_{5}:=0.55 & l_{51}:=0.2 & \beta:=0.34 \mathrm{deg} & \alpha:=36.336 \mathrm{deg} .
\end{array}
$$

The parameters of vector $l_{0}$ are

$$
\begin{gathered}
\mathrm{l}_{0}:=\sqrt{\left(\mathrm{x}_{\mathrm{G}}-\mathrm{x}_{\mathrm{A}}\right)^{2}+\left(\mathrm{y}_{\mathrm{G}}-\mathrm{y}_{\mathrm{A}}\right)^{2}} \quad \phi_{0}:=\pi+\operatorname{atan}\left(\frac{\mathrm{y}_{\mathrm{G}}-\mathrm{y}_{\mathrm{A}}}{\mathrm{x}_{\mathrm{G}}-\mathrm{x}_{\mathrm{A}}}\right) \\
\mathrm{l}_{0}=0.9192 \quad \phi_{0}=112.38 \mathrm{deg}
\end{gathered}
$$

Solution of simultaneous equations $(1,2)$, for example, for the value of the angle $\varphi_{1}=45^{\circ}$ is

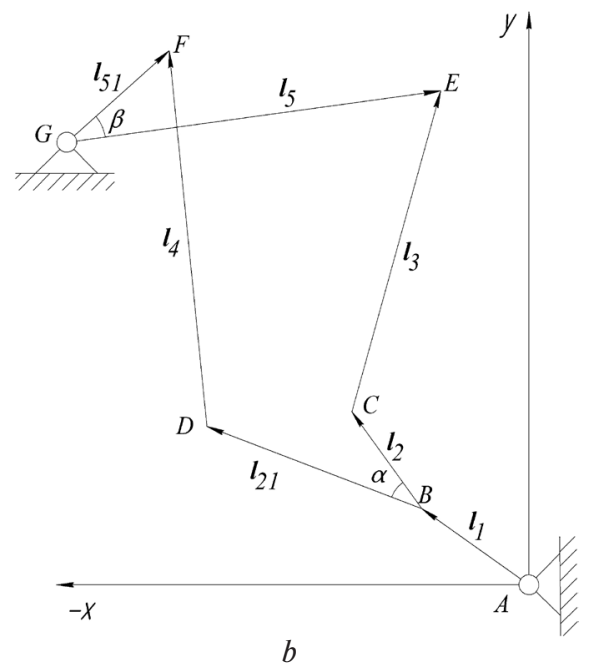




$$
\begin{aligned}
& \phi_{1}=45 \operatorname{deg} \\
& \phi_{2}:=0 \quad \phi_{3}:=1.5 \quad \phi_{4}:=1.5 \quad \phi_{5}:=0 \quad \text { Given } \\
& 1_{1} \cdot \exp \left(\phi_{1} \cdot \mathrm{i}\right)+1_{2} \cdot \exp \left(\phi_{2} \cdot \mathrm{i}\right)+1_{3} \cdot \exp \left(\phi_{3} \cdot \mathrm{i}\right)=1_{0} \cdot \exp \left(\phi_{0} \cdot \mathrm{i}\right)+1_{5} \cdot \exp \left(\phi_{5} \cdot \mathrm{i}\right) \\
& 1_{1} \cdot \exp \left(\phi_{1} \cdot \mathrm{i}\right)+1_{21} \cdot \exp \left[\left(\phi_{2}+\alpha\right) \cdot \mathrm{i}\right]+1_{4} \cdot \exp \left(\phi_{4} \cdot \mathrm{i}\right)=1_{0} \cdot \exp \left(\phi_{0} \cdot \mathrm{i}\right)+1_{51} \cdot \exp \left[\left(\phi_{5}+\beta\right) \cdot \mathrm{i}\right] \\
& \left(\begin{array}{ll}
\phi_{2} & \phi_{3} \\
\phi_{4} & \phi_{5}
\end{array}\right):=\text { Find }\left(\begin{array}{ll}
\phi_{2} & \phi_{3} \\
\phi_{4} & \phi_{5}
\end{array}\right) \\
& \phi_{2}=0.15 \quad \phi_{3}=1.504 \quad \phi_{4}=1.985 \quad \phi_{5}=0.236
\end{aligned}
$$

Having changed only the initial approximation of the angle $\varphi_{2}$ from 0 to 2 radians, we will obtain mechanism assembly 2 for $\varphi_{1}=45^{\circ}$.

$$
\begin{gathered}
\phi_{1}=45 \mathrm{deg} \\
\phi_{2}:=2 \quad \phi_{3}:=1.5 \quad \phi_{4}:=1.5 \quad \phi_{5}:=0 \quad \text { Given } \\
1_{1} \cdot \exp \left(\phi_{1} \cdot \mathrm{i}\right)+1_{2} \cdot \exp \left(\phi_{2} \cdot \mathrm{i}\right)+1_{3} \cdot \exp \left(\phi_{3} \cdot \mathrm{i}\right)=1_{0} \cdot \exp \left(\phi_{0} \cdot \mathrm{i}\right)+1_{5} \cdot \exp \left(\phi_{5} \cdot \mathrm{i}\right) \\
1_{1} \cdot \exp \left(\phi_{1} \cdot \mathrm{i}\right)+1_{21} \cdot \exp \left[\left(\phi_{2}+\alpha\right) \cdot \mathrm{i}\right]+1_{4} \cdot \exp \left(\phi_{4} \cdot \mathrm{i}\right)=1_{0} \cdot \exp \left(\phi_{0} \cdot \mathrm{i}\right)+1_{51} \cdot \exp \left[\left(\phi_{5}+\beta\right) \cdot \mathrm{i}\right] \\
\left(\begin{array}{ll}
\phi_{2} & \phi_{3} \\
\phi_{4} & \phi_{5}
\end{array}\right):=\text { Find }\left(\begin{array}{ll}
\phi_{2} & \phi_{3} \\
\phi_{4} & \phi_{5}
\end{array}\right) \\
\phi_{2}=2.193 \quad \phi_{3}=1.386 \quad \phi_{4}=1.715 \quad \phi_{5}=0.304
\end{gathered}
$$

Enumeration of possible combinations of the initial values of four unknowns with the purpose of searching for all the assemblies of the fourth class structural group is rather time-consuming and does not ensure validity of the obtained result. Graphical-analytic determination of assemblies of this group with a fixed po- sition of the input crank $A B$ will be more reliable.

For this purpose let us consider the four-bar linkage $B C E G$ (Fig. 3, $a$ ). We define vector $l_{c g}$, connecting points $C$ and $G$ (here and elsewhere all the mathematical manipulations are given as fragments of Mathcad documents) as a function of link 2 rotation angle.

$$
\begin{gathered}
\text { Four-bar linkage BCEG } \quad \phi_{1}=45 \mathrm{deg} \quad \phi_{2}=125.6 \mathrm{deg} \\
\mathrm{l}_{\mathrm{cg}}\left(\phi_{2}\right):=1_{0} \cdot \exp \left(\mathrm{i} \cdot \phi_{0}\right)-\mathrm{l}_{2} \cdot \exp \left(\mathrm{i} \cdot \phi_{2}\right)-\mathrm{l}_{1} \cdot \exp \left(\phi_{1} \cdot \mathrm{i}\right) \quad \phi_{\mathrm{cg}}\left(\phi_{2}\right):=\arg \left(1_{\operatorname{cg}}\left(\phi_{2}\right)\right) \\
\left|1_{\operatorname{cg}}\left(\phi_{2}\right)\right|=0.821 \quad \phi_{\mathrm{cg}}\left(\phi_{2}\right)=115.7 \mathrm{deg}
\end{gathered}
$$

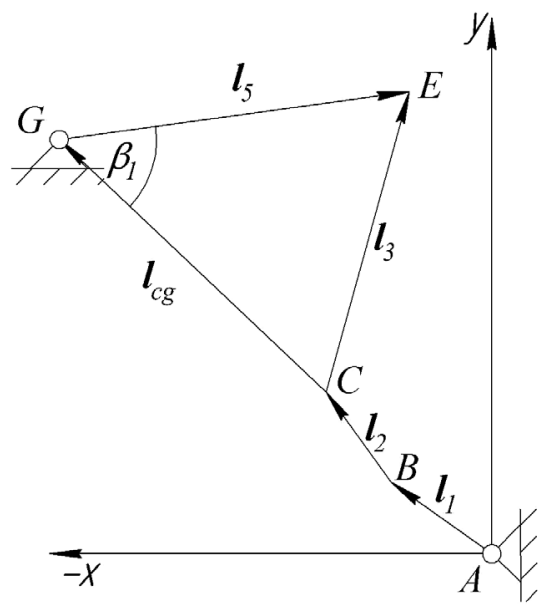

$a$

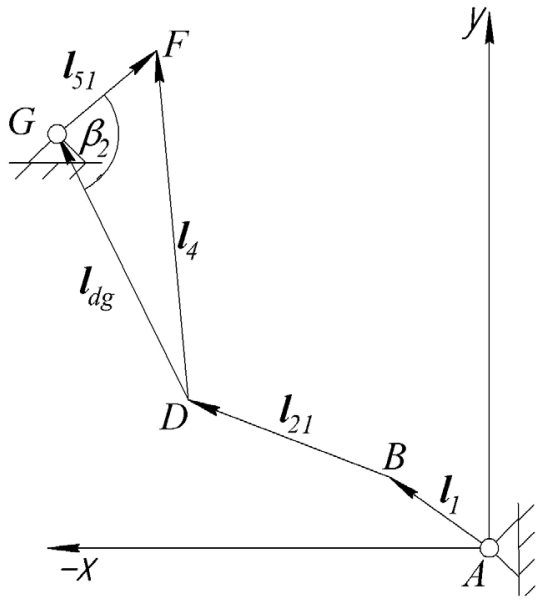

$b$

Fig. 3. Splitting of the the fourth class group as two four-bar linkages:

$a-B C E G ; b-B D F G$ 
The angle $\beta_{1}$ (Fig. 3, $a$ ) is

$$
\beta_{1}\left(\phi_{2}\right):=\operatorname{acos}\left[\frac{1_{5}{ }^{2}-1_{3}{ }^{2}+\left(\left|1_{\operatorname{cg}}\left(\phi_{2}\right)\right|\right)^{2}}{2 \cdot 1_{5} \cdot\left|1 \operatorname{cg}\left(\phi_{2}\right)\right|}\right] \quad \beta_{1}\left(\phi_{2}\right)=81.74 \mathrm{deg}
$$

The angles which define the direction of vectors $l_{5}$ and $l_{3}$ are

$$
\begin{array}{ll}
\phi_{5}\left(\phi_{2}\right):=\phi_{\operatorname{cg}}\left(\phi_{2}\right)+\beta_{1}\left(\phi_{2}\right)-\pi & \phi_{5}\left(\phi_{2}\right)=17.44 \mathrm{deg} \\
\phi_{3}\left(\phi_{2}\right):=\arg \left(1_{\operatorname{cg}}\left(\phi_{2}\right)+1_{5} \cdot \exp \left(\mathrm{i} \cdot \phi_{5}\left(\phi_{2}\right)\right)\right) & \phi_{3}\left(\phi_{2}\right)=79.42 \mathrm{deg}
\end{array}
$$

Let is carry out analogous actions of the four-bar linkage $B D F G$ (Fig. 3, b). Let us define vector $l_{d g}$, connecting points $C$ and $G$ as a function of the angle $\varphi_{2}$.

$$
\begin{aligned}
& \text { Four-bar linkage BDFG } \\
& \begin{array}{l}
1_{d g}\left(\phi_{2}\right):=1_{0} \cdot \exp \left(\mathrm{i} \cdot \phi_{0}\right)-1_{21} \cdot \exp \left[\mathrm{i} \cdot\left(\phi_{2}+\alpha\right)\right]-1_{1} \cdot \exp \left(\phi_{1} \cdot \mathrm{i}\right) \\
\phi_{\mathrm{dg}}\left(\phi_{2}\right):=\arg \left(\mathrm{l}_{\mathrm{dg}}\left(\phi_{2}\right)\right) \quad\left|\mathrm{l}_{\mathrm{dg}}\left(\phi_{2}\right)\right|=0.797 \quad \phi_{\operatorname{dg}}\left(\phi_{2}\right)=108.8 \mathrm{deg}
\end{array}
\end{aligned}
$$

The angle $\beta_{2}$ (Fig. $\left.3, b\right)$ is

$$
\beta_{2}\left(\phi_{2}\right):=\operatorname{acos}\left[\frac{1_{51}{ }^{2}-1_{4}^{2}+\left(\left|l_{d g}\left(\phi_{2}\right)\right|\right)^{2}}{2 \cdot 1_{51} \cdot\left|1_{d g}\left(\phi_{2}\right)\right|}\right] \quad \beta_{2}\left(\phi_{2}\right)=122.6 \mathrm{deg}
$$

The angles which define the direction of vectors $l_{51}$ and $l_{4}$ are

$$
\begin{aligned}
& \phi_{51}\left(\phi_{2}\right):=\phi_{\mathrm{dg}}\left(\phi_{2}\right)+\beta_{2}\left(\phi_{2}\right)-\pi \quad \phi_{51}\left(\phi_{2}\right)=51.44 \mathrm{deg} \\
& \phi_{4}\left(\phi_{2}\right):=\arg \left[1_{\mathrm{dg}}\left(\phi_{2}\right)+1_{51} \cdot \exp \left[\mathrm{i} \cdot\left(\phi_{5}\left(\phi_{2}\right)+\beta\right)\right]\right] \quad \phi_{4}\left(\phi_{2}\right)=98.26 \mathrm{deg}
\end{aligned}
$$

We now proceed to visualizing the obtained results. Let us form the dependency of the angles $\varphi_{5}$ and $\varphi_{51}-\beta$ as a function of the angle $\varphi_{2}$. The intersection points of the built curves will characterise possible assemblies of the studied structural group of the fourth class with the given position of the input link. Changing the angle $\varphi_{1}$ from 0 to $2 \pi$, for example, in $\pi / 4$, we can be certain that the group considered has only two assemblies and this number does not depend on the value of the angle $\varphi_{1}$. Fig. 4 exemplifies this condition for four values of the angle $\varphi_{1}$.

For example, we can approximately define the values of the angle $\varphi_{2}$ (for assembly 1 it is 0 radian; for assembly 2 it is 2 radians) in the graph for the angle $\varphi_{1}=180^{\circ}$ (Fig. 4) using "Trace" tool; these values characterise different assemblies. Further, using the values as initial approximations, we find precise values of all unknown angles in the Given-Find block. In our example these values are:

Assembly 1

$$
\begin{array}{ll}
\phi_{2}=0.43 \mathrm{deg} & \phi_{3}=77.909 \mathrm{deg} \\
\phi_{4}=105.46 \mathrm{deg} & \phi_{5}=5.232 \mathrm{deg}
\end{array}
$$

Assembly 2

$$
\begin{array}{ll}
\phi_{2}=117.246 \mathrm{deg} & \phi_{3}=71.142 \mathrm{deg} \\
\phi_{4}=89.98 \mathrm{deg} & \phi_{5}=9.133 \mathrm{deg}
\end{array}
$$

From the same figure for $\varphi_{1}=270^{\circ}$ it is apparent that the two assemblies are situated quite closely. Their parameters are:
Assembly 1

$$
\begin{array}{ll}
\phi_{2}=46.943 \mathrm{deg} & \phi_{3}=80.798 \mathrm{deg} \\
\phi_{4}=103.26 \mathrm{deg} & \phi_{5}=4.48 \mathrm{deg}
\end{array}
$$

Assembly 2

$$
\begin{array}{ll}
\phi_{2}=76.367 \mathrm{deg} & \phi_{3}=78.746 \mathrm{deg} \\
\phi_{4}=98.65 \mathrm{deg} & \phi_{5}=5.76 \mathrm{deg}
\end{array}
$$

Jaw crushers, which are used in mining industry, feature high forces in effect and heavy wear of conjugate surfaces. Due to deformation of links and splits in joints, proximity of two assemblies can result in transition from one assembly to the other and, subsequently, change in technological parameters of the mechanism right up to jamming for heavy loaded mechanisms.

Therefore, at the synthesis stage for a high class linkage, these machines require conducting a geometry analysis with the purpose of avoiding two assemblies located in close proximity.

Fig. 5 shows two assemblies of the Assur group under consideration with $\varphi_{1}=270^{\circ}$.

Now let us consider the angle $\delta$ (Fig. 1) whose change determines technological parameters of the jaw crusher, namely: reduction ratio, compression strokes in lower and upper sections of a crushing chamber, etc. The variants of change of this angle for the two assemblies are presented in Fig. 6.

It is easily seen that the angle $\delta$ changes negligibly in assembly 2 and hardly provides the required function of 


$$
\phi_{1}=0 \mathrm{deg}
$$

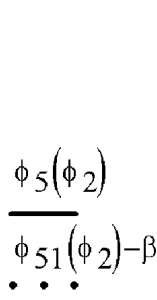

$\frac{\phi_{5}\left(\phi_{2}\right)}{\phi_{51}\left(\phi_{2}\right)-\beta}$

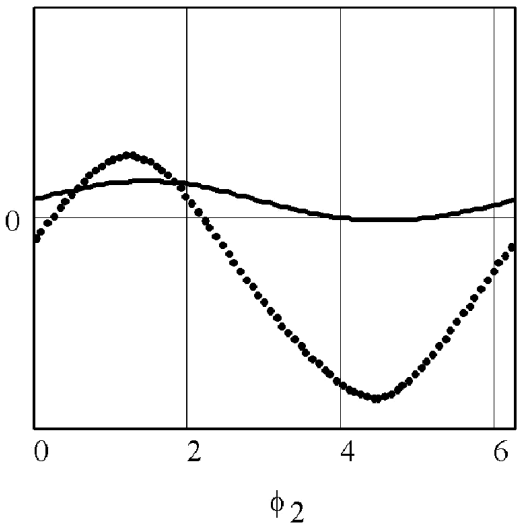

$\phi_{1}=180 \mathrm{deg}$

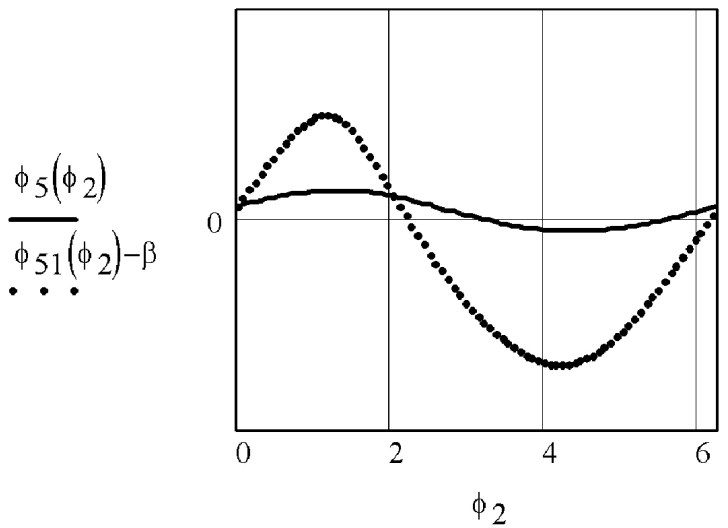

$\phi_{1}=90 \mathrm{deg}$
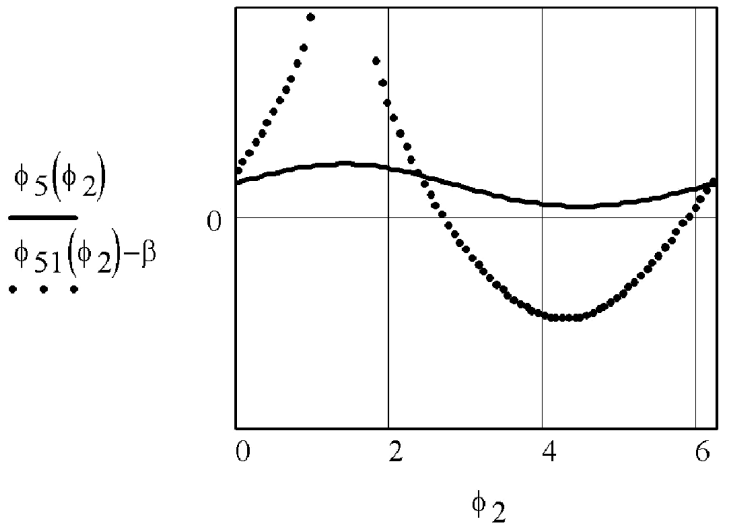

$\phi_{1}=270 \mathrm{deg}$

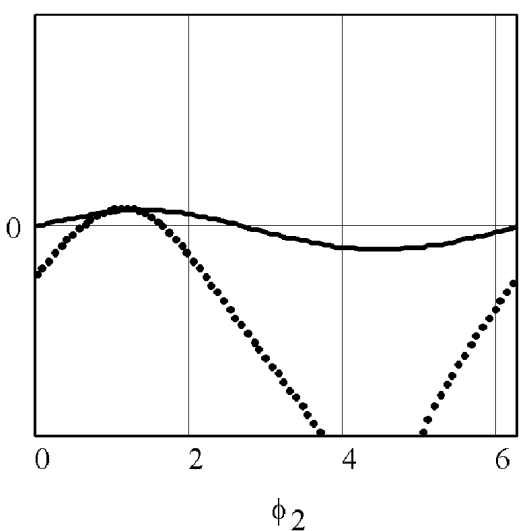

Fig. 4. Assemblies of fourth class Assur group for the values of the angle $\varphi_{1}=0^{\circ}, 90^{\circ}, 180^{\circ}$ and $270^{\circ}$

crushing process.

Apart from considering this mechanism for using in a crusher while regarding it broadly, we can, for example, compare the position functions of the mechanism for its two assemblies taking link 5 as an output one (Fig. 7).

This case also proves the difference between position functions of the mechanism.

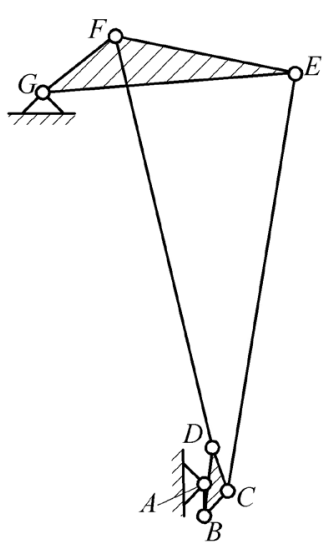

a

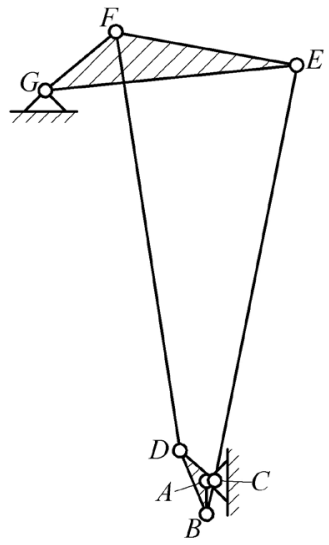

$b$
Fig. 5. Two mechanism versions with $\varphi_{1}=270^{\circ}$ :

$a$ - assembly 1; $b$ - assembly 2
Conclusions. Theoretical research on geometry of planar four-bar Assur group of the fourth class of the linkage of a jaw crusher in which both jaws move has been conducted.

It has been established that the number of possible assemblies in this mechanism equals two.

Technological parameters of crushing process depend on the assembly mode. Assemblies can be in

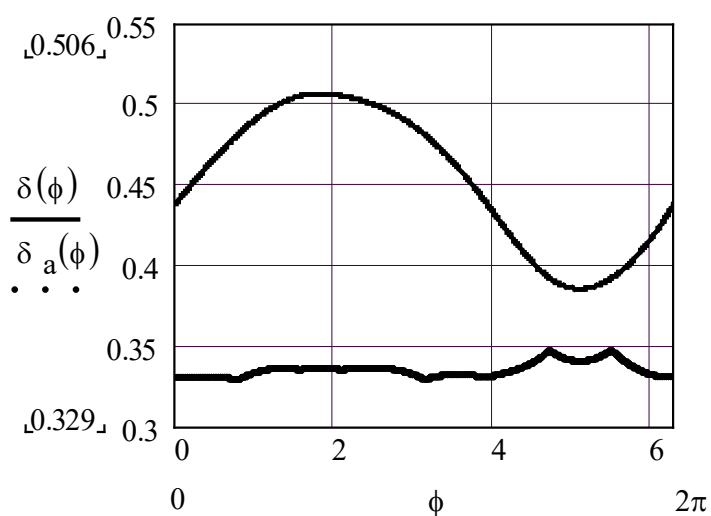

Fig. 6. Angle change between the direct axes of jaws depending on the rotational angle of the input crank:

$\delta(\varphi)-$ assembly $1 ; \delta_{a}(\varphi)-$ assembly 2 


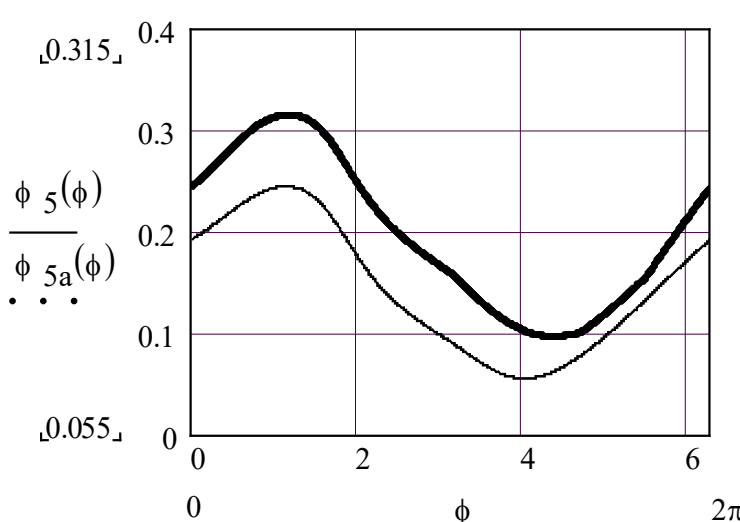

Fig. 7. Relation of the link 5 rotation angle as a function of a crank rotation angle for two mechanism assemblies:

$\varphi_{5}(\varphi)-$ assembly $1 ; \varphi_{5 a}(\varphi)-$ assembly 2

close proximity, which may result in an emergency situation.

The synthesis of high class mechanisms is to be conducted regarding the conclusions made in the article; for this purpose the research algorithm suggested can be applied.

\section{References.}

1. Dvornikov, L. T. and Starikov, S. P., 2006. Kinematics and kinetostatics of the planar six-bar Assur group of fourth class. The Theory of Mechanisms and Machines [pdf], 1(4), pp. 61-65. Available at: <http://tmm.spbstu. ru/7/dvornikov-starikov.pdf> [Accessed 23 April 2017].

2. Tuleshov, E. A. and Drakunov, Yu. M., 2010. Vector Method Of Kinematic Analysis Of Third Class Mechanism [online]. In: Proceedings of The international scientific-technical conference "The 3-D Erzhanov's Reading", Aktobe, pp. 206-209.

3. Matsyuk, I. M., Morozova, T. I. and Shlyahov, E. M., 2017. Search of variants of assemblies of structural groups in planar linkages. Naukovyi Visnyk Natsionalnoho Hirnychoho Universytetu, 2, pp. 65-69.

4. Franchuk, V. P., Ziborov, K.A., Krivda, V. V. and Fedoriachenko, S. O., 2017. On wheel rolling along the rail regime with longitudinal load. Naukovyi Visnyk Natsionalnoho Hirnychoho Universytetu, 3, pp. 62-67.

5. Moldovan, C. E., Lovasz, E.-C., Perju, D., Modler, K.-H. and Maniu, I., 2015. On the Kinematic Analysis of the fourth class Mechanisms. In: Proc. of the $14^{\text {th }}$ IFToMM World Congress, Taipei, Taiwan, 25-30 October 2015, OS8-023 [pdf], 4, pp. 2447-2453. Available at: $<$ www.iftomm2015.tw/IFToMM2015CD/PDF/ OS8023.pdf $>$ [Accessed 14 August 2017].

6. Moldovan, C.E., Perju, D., Lovasz, E.-C., Modler, K.-H. and Maniu, I., 2017. On the Kinematic Analysis of a Sixth Class Mechanism. Mechanisms and Machine Science, book series, 46, pp. 47-59.

\section{Деякі аспекти синтезу важільних механізмів складної структури}

$$
\text { I. М. Мацюк }{ }^{1} \text {, Е. М. Шляхов }{ }^{1} \text {, O. I. Егурнов }{ }^{2}
$$

1 - Державний вищий навчальний заклад „Національний гірничий університет“, м. Дніпро, Україна, е-mail: shlyahove@nmu.org.ua

2 - ВАТ „Ана-Темс“, м. Дніпро, Україна, е-mail: yegurnov@yahoo.com

Мета. Оцінити вплив різних варіантів складань двоповідкової структурної групи четвертого класу на працездатність механізму, що їх містить.

Методика. У роботі виконано теоретичне дослідження можливих складань структурної групи четвертого класу в механізмі двощокової дробарної машини 3 використанням програмного продукту Mathcad.

Результати. Показано, що у пласкій ассуровій групі четвертого класу, що застосовується у дробарних машинах:

- для прийнятого розташування трипарних ланок відносно стійки можливо лише два складання;

- вид складання істотно впливає на якість процесу подрібнення;

- складання можуть розташовуватися дуже близько, що у важко навантажених механізмах може спричинити самовільний перехід з одного складання в інше і, як наслідок, створити аварійну ситуацію.

Наукова новизна. Встановлено, що у пласкій чотириланковій структурній групі четвертого класу кількість можливих складань не перевищує двох. Можливі випадки дуже близького взаємного розташування складань. Функції положення механізмів з різними складаннями відрізняються одна від одної.

Практична значимість. Запропоновано алгоритм дій, що дозволяють при синтезі пласких механізмів четвертого класу оцінювати їх можливі складання.

Ключові слова: структурна група, складання механізму, геометричний аналіз, щокова дробарка, програма Mathcad

\section{Некоторые аспекты синтеза рычажных механизмов сложной структуры}

\section{И. Н. Мацюк ${ }^{1}$, Э. М. Шляхов ${ }^{1}$, А. И. Егурнов ${ }^{2}$}

1 - Государственное высшее учебное заведение „Национальный горный университет“, г. Днепр, Украина, e-mail: shlyahove@nmu.org.ua

2 - ООО „Ана-Темс“, г. Днепр, Украина, e-mail: yegurnov@yahoo.com

Цель. Оценить влияние различных вариантов сборок двухповодковой структурной группы четвертого класса на работоспособность механизма ее содержащего.

Методика. В работе выполнено теоретическое исследование возможных сборок структурной группы четвертого класса в механизме двухщековой дробильной машины с использованием программного продукта Mathcad.

Результаты. Показано, что в плоской ассуровой группе четвертого класса, применяемой в дробильной машине: 
- для принятого расположения трехпарных звеньев относительно стойки возможны всего две сборки;

- вид сборки существенно влияет на качество процесса дробления;

- сборки могут располагаться весьма близко, что в тяжелонагруженных механизмах может повлечь самопроизвольный переход из одной сборки в другую и, как следствие, создать аварийную ситуацию.

Научная новизна. Установлено, что в плоской четырехзвенной структурной группе четвертого класса число возможных сборок не превышает двух. Возможны случаи весьма близкого взаимного расположения сборок. Функции положения механизмов с различными сборками отличаются друг от друга.

Практическая значимость. Предложен алгоритм действий, позволяющий при синтезе плоских механизмов четвертого класса оценивать их возможные сборки.

Ключевые слова: структурная группа, сборки механизма, геометрический анализ, щековая дробилка, программа Mathcad

Рекомендовано до публікації докт. техн. наук В. В. Процівом. Дата надходження рукопису 10.03.17. 